\title{
Jews in Ukraine: Anti-Semitism
}

\section{A. Polyakov}

Corrupted Soviet structures are disintegrating and moving towards total destruction, which will create a vacuum in the executive power. In the midst of a profound economic crisis and a struggle for a nationalist movement, Jews are the most vulnerable in the population.

The consolidation of antidemocratic forces in Russia clearly indicates the unifying role of the "Jewish factor." There is a strong possibility that this process may spread to Ukraine. Nine out of ten people interviewed in our survey believe that is a distinct possibility-that anti-Semitism in Ukraine has long roots, and that no significant changes have occurred. Official public assurances to the contrary have a political character and may change under the pressure of political circumstances.

This is the opinion of an overwhelming majority-eight or nine out of ten people interviewed in the survey.
As for the so-called "revival of Jewish culture" in Ukraine, it is true that we are trying to take advantage of the situation that allows us, at least for the moment, to restore our national pride, to teach our children, to renew activities of religious communities, to restore traditions, holy days and knowledge of Hebrew, etc. In the last one and a half years, a number of Jewish organizations, newspapers and theatres have sprung up. In spite of all this, the majority of Jews do not see it as a "revival." Only less than five percent of the Jewish population participate in these organizations and establishments. Some rather important organizations were in fact created from "above," in order to demonstrate the "harmony of interethnic relations at a new stage of the development of Soviet society."

The remaining 95 percent of Jews feel uncertain and fearful of their future in Ukraine. This fear is nourished by the growing number of attacks on Jews. We haveevidence of pogroms in synagogues and schools in Kiev, Kirovograd and Dnietropetrovs, of assaults on the members of "Beitar" (a Zionist youth organization), of people spreading antiSemitic literature in Russia, and other acts.

All these examples can be viewed as individual acts. However, in the framework of the political struggle between Ukraine and Moscow and the present economic situation, these provocative attempts to focus the Ukrainian population's attention on the relations between Ukrainians and Jews can lead to unforeseen consequences, including scapegoating. Under these circumstances, a growing majority of the Jewish population do not wish to stay in Ukraine and are considering emigration. 圆

A. Polyakov, who passed away recently, was the Director of the Kiev Bureau of Human Rights, Ukraine.

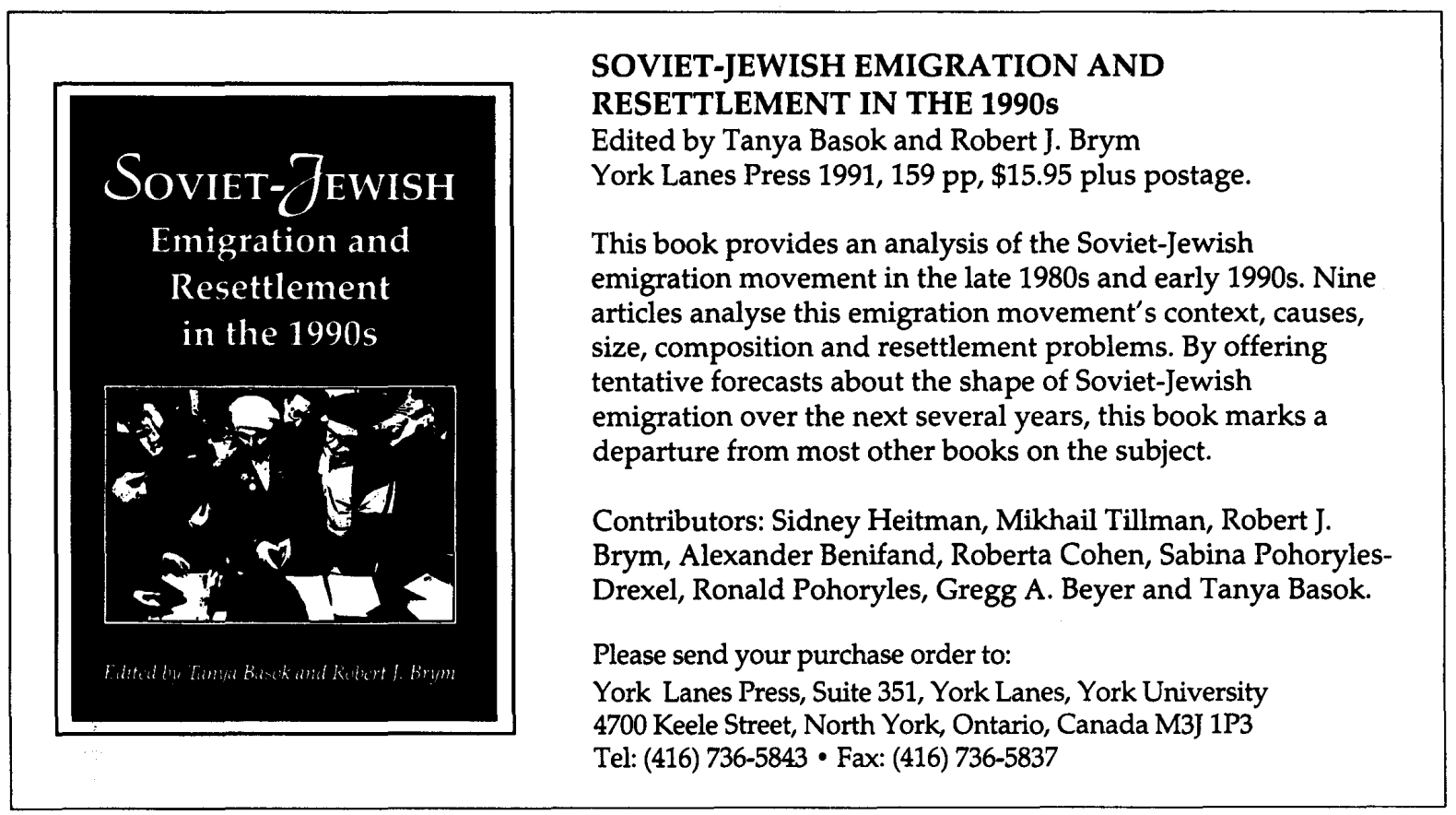




\section{CENTRE FOR REFUGEE STUDIES ANNUAL DINNER AND MEETING Jade Garden Restaurant 222 Spadina Avenue, Toronto February 4, 1993}

\section{DONOR INFORMATION}

Corporate Patron A table for ten to the dinner plus a subscription to Refuge and notification of events sponsored by the Centre

Patron

One ticket for the dinner

plus a subscription to Refuge and notification of events sponsored by the Centre

Friend

$$
\text { One ticket to the dinner }
$$

Special student rate

\section{REGISTRATION FORM}

I would like reserve table(s).

Total number of dinner tickets required:

I wish to renew my support. Enclosed is my cheque in the amount of:
$\square \$ 600$
$\square \$ 125$
$\square \$ 60$
$\square \$ 30$
$\$$

I will attend the dinner on February 4, 1993.
Menu preference:
Regular
Vegetarian

I cannot attend, but I am sending a donation to the Centre.

Method of payment: $\square$ Cheque. Please make cheque payable to: Centre for Refugee Studies

Charge to my: $\square$ Visa $\square$ MasterCard $\square$ Amex

Card number Expiry Date:

Card holder's name:

Signature:

Please send official tax receipts, correspondence, publications and dinner tickets to:

Name

Organization

Address

City Postal Code

Tel: Fax:

Please send or fax your completed form to:

Centre for Refugee Studies, Suite 311, York Lanes, York University 4700 Keele Street, North York, ON M3J 1P3

Fax: (416) 736-5837 • Tel: (416) 736-5663 


\section{Refuge \\ York Lanes Press \\ Centre for Refugee Studies \\ Suite 351, York Lanes, York University \\ 4700 Keele Street, North York \\ Ontario, Canada M3J 1P3 \\ Phone: (416) 736-5843 - Fax: (416) 736-5837 \\ Electronic Mail via Bitnet Address: \\ REFUGE @YORKVM1}

Postage Paid in Toronto, Canada

Second Class Mail Registration No. 5512

Return Postage Guaranteed

\title{
CONFERENCE
}

\section{Racism, Aboriginality, Ethnicliy and Gender In Australia, Canada, New Zealand and the United States}

\author{
Universtry of TechNoloov, SYoner, Australia \\ Novemaer 25-27, 1993
}

Papers are invited on the following themes:

- the social construction of aboriginality, ethnicity, "race" and gender

- contemporary dimensions of racism

- antiracist strategies:

- racial discrimination in the workplace and the community

- multiculturalism and racism

- state policies and practices

- community responses and strategies

Papers can be from contemporary, historical, comparative or single country perspectives.

Community involvement is encouraged. Abstracts should be sent to the conference organizer by the end of May 1993:

Jock Collins, Associate Professor

School of Finance and Economics

University of Technology

Sydney, NSW 2007

Australia

The conference proceedings will be published. Negotiations with a number of publishers are underway. We would appreciate early notice of interest in the conference. A newsletter will be sent in early 1993 to outline the arrangements foraccommodation and the conference. Funds are not available to pay for airfares, although a letter of invitation to attend the conference can be arranged. 